\title{
A utilização do método coaching no processo de liderança do profissional de enfermagem nas organizações de saúde: um relato de experiência
}

\author{
Alan Rodrigues de Souza, Graziele Carolina de Almeida Marcolin, Mateus Marcolin, Amanda
}

Conrado Silva Barbosa, Marília Sueli da Silva Azevedo Almeida

\begin{abstract}
Resumo
De acordo com a realidade das organizações de saúde, a carência de profissionais qualificados, criativos, proativos e que estejam estruturados emocionalmente com vistas à necessidade do ser humano ser reconhecido em sua totalidade, é o que faz com que métodos de melhor organização e planejamento de equipe tornem-se objeto de estudo. O termo inglês "Coach" tem sua origem no mundo dos esportes, designando "o papel de treinador, preparador, técnico", ou seja, em sua essência, o papel a ser exercido por um líder no sentido de orientar sua equipe. Assim, o Coaching é um processo de alto impacto para o aumento da produtividade, uma vez que volta-se ao compromisso com os resultados e com a realização das pessoas, pressupondo uma maior cooperação no âmbito das organizações. Logo, por ser esta uma metodologia consideravelmente nova na saúde, o objetivo deste estudo é analisar os fundamentos em que se baseia o método coaching, identificando-o como uma ferramenta no processo de liderança do profissional de enfermagem nas organizações de saúde. A metodologia utilizada foi o relato de experiência, integrando a análise de materiais obtidos por meio de consulta aos Descritores em Ciências e Saúde, sendo diferentes bases de dados acessadas a fim de nortear esta pesquisa. O contexto observado para elaboração do relato foi uma Unidade Básica de Saúde (UBS) do Município de Conselheiro Lafaiete - MG, no qual, atualmente, o Enfermeiro tem se utilizado da metodologia para melhor nortear a atuação de seus técnicos e agentes. Os principais resultados demonstraram que quando a equipe está muito competitiva, a prática de coaching pode favorecer o restabelecimento de vínculos entre as pessoas, assim como a preocupação com o desenvolvimento dos outros. No entanto, quando se trata de uma equipe que "coopera demais", há uma provocação iminente de reflexão acerca das responsabilidades pelos resultados. Além disso, esta pode ser vista como uma ferramenta que favorece a cultura organizacional, predominando relacionamentos cooperativos, troca constante de conhecimentos, experiências, informações e feedbacks entre a equipe; sendo estes elementos relevantes para a aprendizagem, desenvolvimento pessoal e profissional dos membros da organização, uma vez que são constantemente encorajados a refletir sobre o sentido do seu trabalho, compartilhando idéias e opiniões acerca de um tema ou problema. Na UBS em na análise, além dos aspectos observados, pode-se dizer que o coaching tornou-se uma ferramenta indispensável para a organização, pois auxiliou efetivamente na atuação do profissional de enfermagem como líder da equipe, assim como norteou ações mais concisas e direcionadas com os técnicos e agentes de saúde da organização. Logo, o coaching deve ser um método utilizado por todos os gestores no dia-a-dia das organizações. Contudo, nem todos encontram-se aptos a aplicá-lo e alguns deles nem ao menos o conhecem ou reconhecem seus benefícios para com o desenvolvimento das organizações de saúde. Por este fato, estudos empíricos na área devem ser procedidos a fim de melhor nortear as ações do Enfermeiro como líder no contexto de gestão das organizações de saúde.
\end{abstract}

Descritores: Coaching; Enfermagem; Organizações de Saúde 